\title{
Alfalfa Rotation Strategy and Soil Type Influence Soil Characteristics and Replanted Alfalfa Yield in the Irrigated Semiarid, Subtropical Southwestern USA
}

\author{
Leonard M. Lauriault * and Murali K. Darapuneni \\ Rex E. Kirksey Agricultural Science Center, New Mexico State University, Tucumcari, NM 88401, USA; \\ dmk07@nmsu.edu \\ * Correspondence: 1mlaur@nmsu.edu; Tel.: +1-575-461-1620
}

\begin{abstract}
Alfalfa (Medicago sativa L.) establishment failure is often attributed to autotoxicity when alfalfa is reseeded shortly after termination of the previous alfalfa stand, but renovation/rotation strategies for irrigated semiarid, subtropical environments have not been studied. Two identical studies were initiated at the New Mexico State University Rex E. Kirksey Agricultural Science Center at Tucumcari, NM, USA to compare continuous alfalfa (ALF), a single year of rotation to sorghum-sudangrass (SS1; Sorghum bicolor $\times$ S. sudanense (Piper) Stapf), two years of rotation with sorghum-sudangrass (SS2), and winter wheat forage (Triticum aestivum L.) followed by a single season of sorghum-sudangrass (WW/SS). Soil type and renovation/rotation strategy may influence soil fertility prior to replanting alfalfa, but soil fertility did not appear to influence alfalfa re-establishment or first production year yields. With a Test $\mathrm{x}$ Rotation interaction due to differences between tests for WW/SS for first production year yield after September alfalfa replanting, the main effect of Rotation was significant for yield $\left(6.43 \mathrm{AB}, 5.3 \mathrm{~B} 0,6.92 \mathrm{~A}\right.$, and 3.54C $\mathrm{Mg} \mathrm{ha}^{-1}$ for ALF, SS1, SS2, and WW/SS, respectively; $5 \% \mathrm{LSD}=1.22$ ). Alfalfa stand destruction and replanting with no intervening crop rotation may be feasible in sandy soils with irrigation in the semiarid, subtropical southwestern USA and similar environments.
\end{abstract}

Keywords: alfalfa; allelopathy; autotoxicity; irrigation; renovation; soil; sorghum; wheat

\section{Introduction}

Allelopathy is a plant response, often developed due to a stress factor [1], to minimize competition for resources by neighboring plants [2,3]. Autotoxicity is a form of allelopathy directed against seedlings of the same species [3,4]. Alfalfa (Medicago sativa L.) establishment failure is often attributed to autotoxicity when alfalfa is reseeded shortly after termination of the previous alfalfa stand [2-5]. The autotoxicity can either inhibit or reduce final germination $[3,4]$ or reduce yields over the life of the stand due to autoconditioning [2,5], possibly because seedling root growth is most affected [3].

While many potential allelopathic chemical components have been identified in alfalfa, none have been proven to be the sole factor in autotoxicity [3], but most allelopathic compounds are known to be water soluble [4], being leached or exuded from plant parts into the soil $[5,6]$. Extracts from alfalfa leaves are more strongly allelopathic than extracts from seeds [3,7] and roots [7]. Over time, these allopathic compounds are leached below the root zone or converted to non-lethal substances by microbial activity [5,6]. Multiple studies have reported various times ranging from little or no delay to at least a year that are necessary to delay replanting alfalfa after previous stand termination due to reduced productivity $[2,5,7,8]$. The longer intervals encourage rotation to other crops that include tillage to help dissipate the toxins; as reported by Jennings and Nelson [2], dead alfalfa plants had the same effect on seedlings as live plants after replanting with no-tillage at one of two locations 1 year after herbicide application. They [2] partially attributed the location difference to soil type (both silt loam). 
In addition to alleviating alfalfa autotoxicity [6], crop rotation following alfalfa to grass crops is beneficial for weed control [9] and transferring $\mathrm{N}$ to the grass to save on fertilizer costs $[7,8]$, but successful destruction of the previous alfalfa stand is necessary to minimize competition with the next crop, maximize $\mathrm{N}$ transfer [8], and assure that no remaining plants cause autotoxicity when the alfalfa is replanted, because even 8 plants $\mathrm{m}^{-2}$ of survivors after termination can reduce seedling survival and stand yield [2,5]. Effective tillage can adequately destroy alfalfa plants, negating the need for herbicides, which may or may not be effective by themselves [5,8]. While considerable information is available about replanting alfalfa to avoid the effects of autotoxicity in higher precipitation temperate regions under field conditions, the literature is lacking in studies about rotations for replanting alfalfa in semiarid, subtropical regions.

The objectives of this study were to evaluate crop rotation strategies for renovating old alfalfa stands to mitigate autotoxicity when replanting alfalfa in semiarid, subtropical regions and the influence of those Rotations on soil characteristics at replanting time and replanted alfalfa yield.

\section{Materials and Methods}

Two identical studies were initiated in consecutive years at the New Mexico State University Rex E. Kirksey Agricultural Science Center at Tucumcari, NM, USA $\left(35^{\circ} 12^{\prime} 0.5^{\prime \prime} \mathrm{N}\right.$, $103^{\circ} 41^{\prime} 12.0^{\prime \prime} \mathrm{W}$; elev. $1247 \mathrm{~m}$ ). Studies were superimposed on 8- and 7-year-old alfalfa variety tests (designated Tests 1 and 2, respectively) with fairly uniform, but declining, stands. Original stand density differences within the original tests due to stand age and varietal effects were not a concern in this study because Jennings and Nelson [5] reported that original alfalfa stand density influenced neither replanted stand density nor yield, even over a range of 14,21 , and 54 plants $\mathrm{m}^{-2}$.

The soils were Canez (fine-loamy, mixed, thermic Ustollic Haplargid; Test 1) and Quay fine sandy loam (fine-silty, mixed, superactive, thermic Ustic Haplocalcids; Test 2). Prior to initiation of the study, soil samples were collected to $30 \mathrm{~cm}$ deep from each Test area, air dried, and submitted to Ward Laboratories (Kearney, NE, USA; https: / / www.wardlab. com/wp-content/uploads/2021/08/WARDGUIDE-Master-Updated-8.19.21.pdf; accessed on 10 November 2021) for standard analysis using the Olsen test for phosphorus [10]. Soil descriptions and test results before initiation of the study are presented in Table 1.

Table 1. Characteristics and initial soil test results for fine sandy loam soils used in two tests initiated in consecutive years comparing alfalfa rotation strategies at Tucumcari, NM, USA.

\begin{tabular}{|c|c|c|}
\hline Characteristic & Test 1 & Test 2 \\
\hline Series & Canez & Quay \\
\hline Rooting depth & $>1.5 \mathrm{~m}$ & $1 \mathrm{~m}$ \\
\hline Water holding capacity & 229 & 140 \\
\hline Calcareous & Yes & Yes \\
\hline $\mathrm{pH}$ & 8.3 & 8.5 \\
\hline 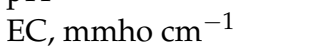 & 0.27 & 31 \\
\hline OM, \% & 0.6 & 0.6 \\
\hline $\mathrm{N}, \mathrm{ppm}$ & 7.4 & 5.7 \\
\hline $\mathrm{P}, \mathrm{ppm}$ & 28 & 23 \\
\hline $\mathrm{K}, \mathrm{ppm}$ & 188 & 234 \\
\hline S, ppm & 7 & 7 \\
\hline Zn, ppm & 0.28 & 0.22 \\
\hline $\mathrm{Fe}, \mathrm{ppm}$ & 5.7 & 7.8 \\
\hline Mn, ppm & 3.7 & 3.9 \\
\hline $\mathrm{Cu}, \mathrm{ppm}$ & 0.18 & 0.44 \\
\hline $\mathrm{Ca}, \mathrm{ppm}$ & 2588 & 2880 \\
\hline $\mathrm{Mg}, \mathrm{ppm}$ & 281 & 320 \\
\hline $\mathrm{Na}, \mathrm{ppm}$ & 48 & 46 \\
\hline CEC & 16 & 17.9 \\
\hline
\end{tabular}


Due to available space and the need for larger plots $(36 \mathrm{~m} \times 7.32 \mathrm{~m})$ during the renovation phase, Test 1 had two replicates and Test 2 had four replicates, both as randomized complete blocks. Renovation strategies included continuous alfalfa (ALF: one month between stand destruction and replanting, with no rotation crop), a single year of rotation to sorghum-sudangrass (SS: Sorghum bicolor $\times$ S. sudanense (Piper) Stapf.; cv. PS210BMR, seeding rate $28 \mathrm{~kg} \mathrm{ha}^{-1}$ ) (SS1: 5 months between stand destruction and alfalfa replanting, with one rotation crop), two years of rotation with SS (SS2: 17 months between alfalfa stand destruction and replanting with two rotation crops), and winter wheat forage (WW: Triticum aestivum L.; cv Weather Master 135, seeding rate $67 \mathrm{~kg} \mathrm{ha}^{-1}$ ) followed by a single season of SS (WW/SS: 12 months between alfalfa stand destruction with two rotational crops). Rotations are shown as a Gannt chart in Table 2 with a timeline of alfalfa stand destruction, rotation, and alfalfa replanting.

Alfalfa stand termination was initiated for each Rotation treatment to have a common late summer alfalfa replanting date within each Test [5]. Tillage for all Rotation treatments consisted of harvesting standing alfalfa forage and then moldboard plowing to approximately $30 \mathrm{~cm}$ deep to terminate the original stand, followed by rototilling and other procedures to prepare a conventionally tilled seedbed formed into eight $0.91 \mathrm{~m}$ wide beds for furrow irrigation. Previously plowed plots were no-till drilled for successive annual crops. Wheat was planted in late August as recommended for forage production and SS was planted in late May after wheat harvest and danger of frost were past. The same no-till drill was used for all planting operations, including replanting the alfalfa, as it was equipped with small legume and grain boxes. The Test areas were irrigated monthly April through October as canal water was available in Years 1 and 2 of each Test, applying approximately $15 \mathrm{~cm}$ per application, which has been found to be sufficient to bring the rooting zone to field capacity and meets or exceeds the water requirement for all crops grown in the study. Wheat was harvested for forage at the boot stage in early May of Year 2 and sorghum-sudangrass was managed as single-cut system each year with a late-season harvest in Year 1 (for SS2) and mid-summer harvest in Year 2 (SS1, SS2, and WW/SS) to allow for alfalfa replanting in late summer (Table 1). Because of the photoperiod-sensitive nature of the SS cultivar, all harvests for that species were at a vegetative stage [11]. 
Table 2. Gannt diagram for alfalfa renovation treatments at Tucumcari, NM USA.

\begin{tabular}{|c|c|c|c|c|c|c|c|c|c|c|c|c|c|c|c|c|c|c|c|}
\hline \multirow[b]{2}{*}{ Treatment } & \multirow[b]{2}{*}{ Activity } & \multicolumn{6}{|c|}{ Year 1} & \multicolumn{6}{|c|}{ Year 2} & \multicolumn{6}{|c|}{ Year 3} \\
\hline & & May & June & July & Aug & Sep & Oct & May & June & July & Aug & Sep & Oct & May & June & July & Aug & Sep & Oct \\
\hline \multirow[t]{3}{*}{ Continuous alfalfa } & Removed as hay & & & & & & & & & & & & & & & & & & \\
\hline & Stand destroyed & & & & & & & & & & & & & & & & & & \\
\hline & Alfalfa harvested & & & & & & & & & & & & & & & & & & \\
\hline \multirow[t]{6}{*}{ SS, 1 year $(\mathrm{SS} 1)$} & Alfalfa removed as hay & & & & & & & & & & & & & & & & & & \\
\hline & Alfalfa destroyed & & & & & & & & & & & & & & & & & & \\
\hline & SS planted & & & & & & & & & & & & & & & & & & \\
\hline & SS removed as hay & & & & & & & & & & & & & & & & & & \\
\hline & Alfalfa replanted & & & & & & & & & & & & & & & & & & \\
\hline & Alfalfa harvested & & & & & & & & & & & & & & & & & & \\
\hline \multirow[t]{6}{*}{ SS, 2 years (SS2) } & Alfalfa removed as hay & & & & & & & & & & & & & & & & & & \\
\hline & Alfalfa destroyed & & & & & & & & & & & & & & & & & & \\
\hline & SS planted & & & & & & & & & & & & & & & & & & \\
\hline & SS removed as hay & & & & & & & & & & & & & & & & & & \\
\hline & Alfalfa replanted & & & & & & & & & & & & & & & & & & \\
\hline & Alfalfa harvested & & & & & & & & & & & & & & & & & & \\
\hline WW/SS & Alfalfa removed as hay & & & & & & & & & & & & & & & & & & \\
\hline & Alfalfa destroyed & & & & & & & & & & & & & & & & & & \\
\hline & WW planted & & & & & & & & & & & & & & & & & & \\
\hline & SS planted & & & & & & & & & & & & & & & & & & \\
\hline & SS removed as hay & & & & & & & & & & & & & & & & & & \\
\hline & Alfalfa replanted & & & & & & & & & & & & & & & & & & \\
\hline & Alfalfa harvested & & & & & & & & & & & & & & & & & & \\
\hline
\end{tabular}

SS and WW signify sorghum-sudangrass and winter wheat, respectively. Shaded boxes indicate months during which an activity took place. 
During Years 1 and 2, alfalfa was harvested from the ALF treatment plots as growth permitted. No yield measurements were taken from any crop during the renovation period. Prior to replanting the alfalfa, after the ALF plots were moldboard plowed, the entire Test area was rototilled and prepared as a conventionally-tilled seedbed to form $0.91 \mathrm{~m}$ wide beds for furrow irrigation.

In late summer of Year 2 (Table 1), alfalfa (AmeriStand 815T RR, $22.5 \mathrm{~kg} \mathrm{ha}^{-1}$ ) was reseeded on 18 and 20 September in Tests 1 and 2, respectively (Table 2). Immediately after planting, a $5 \mathrm{~cm}$ diameter soil core to $30 \mathrm{~cm}$ deep was taken from each plot and analyzed as previously described. Each Test was irrigated three times between planting and the end of October of Year 2 to maintain a moist surface for alfalfa germination and establishment. Glyphosate (isopropylamine salt of $\mathrm{N}$-(phosphonomethyl)glycine; $93.5 \mathrm{~L} \mathrm{2.5 \%} \mathrm{solution}$ $\mathrm{ha}^{-1}$ with $1.44 \mathrm{~kg}$ ammonium sulfate $100 \mathrm{~L}^{-1}$ ) was applied in late November each seeding year to control weeds and alfalfa plants not having glyphosate tolerance.

In Year 3 (the first production year for each Test), glyphosate was applied again in March for winter weed control and again in June for summer weed control, and fertilizer ( $25 \mathrm{~kg} \mathrm{~N} \mathrm{ha}^{-1}$ and $117 \mathrm{~kg} \mathrm{P}_{2} \mathrm{O}_{5} \mathrm{ha}^{-1}$ ) was applied in April. Each Test was furrow-irrigated once prior to each cutting, beginning in mid-April when canal water generally became available, applying approximately $15 \mathrm{~cm}$ of water with each irrigation, as previously described. The exceptions are that during Year 3 of Test 2, irrigation water was only available from 14 May to 11 July, 18 to 29 August, and 1 September to 14 October, due to persistent drought in the watershed for the surface water source. In Year 3, Test 1 was swathed on 29 May, 29 June, 24 July, 22 August, 18 September, and 30 October and Test 2 was swathed 29 May, 24 July, 18 September, and 30 October. For each harvest, the field was swathed, leaving a $5 \mathrm{~cm}$ stubble and taking care to keep the four center beds of each plot as a swathed unit. After swathing was complete, a $4.57 \mathrm{~m}$ section from the four center beds of each plot was collected near the center of the swath's length and fresh weights were measured in the field. A subsample of the collected material from each plot was weighed, dried at $65^{\circ} \mathrm{C}$ for $48 \mathrm{~h}$, and reweighed to determine dry matter (DM) concentration, which was used to convert plot fresh weights to DM yield. After Year 3 of Test 2, canal water for irrigation was not available due to persistent drought; consequently, the study was terminated. Weather data during the study period were collected within $1.8 \mathrm{~km}$ of the study sites (Table 3 ).

Table 3. Monthly mean temperature and total precipitation for years 1-3 of two alfalfa renovation studies at Tucumcari, NM, USA, and the long-term (1905-2020) averages.

\begin{tabular}{|c|c|c|c|c|c|c|c|c|c|c|}
\hline \multirow{3}{*}{$\begin{array}{l}\text { Test } 1 \text { Year } \\
\text { Test } 2 \text { Year }\end{array}$} & \multicolumn{5}{|c|}{ Temperature, ${ }^{\circ} \mathrm{C}$} & \multicolumn{5}{|c|}{ Precipitation, $\mathrm{mm}$} \\
\hline & 1 & 2 & 3 & - & \multirow{2}{*}{ Long-Term } & 1 & 2 & 3 & - & \multirow{2}{*}{ Long-Term } \\
\hline & - & 1 & 2 & 3 & & - & 1 & 2 & 3 & \\
\hline January & 6.7 & 7.2 & 0.0 & 3.9 & 3.3 & 34 & 2 & 17 & 1 & 10 \\
\hline February & 7.2 & 6.1 & 6.1 & 3.3 & 5.6 & 28 & 0 & 5 & 1 & 13 \\
\hline March & 12.2 & 12.2 & 12.2 & 6.7 & 9.4 & 29 & 5 & 77 & 5 & 19 \\
\hline April & 13.3 & 13.3 & 7.8 & 13.3 & 14.4 & 59 & 18 & 21 & 20 & 28 \\
\hline May & 18.3 & 21.7 & 21.7 & 18.9 & 18.9 & 60 & 29 & 21 & 64 & 47 \\
\hline June & 25.0 & 25.6 & 25.6 & 26.1 & 25.0 & 4 & 44 & 71 & 52 & 47 \\
\hline July & 26.7 & 25.6 & 26.7 & 26.4 & 26.1 & 76 & 82 & 21 & 143 & 66 \\
\hline August & 24.4 & 23.9 & 23.9 & 23.9 & 25.0 & 113 & 130 & 32 & 92 & 68 \\
\hline September & 23.3 & 18.3 & 23.3 & 20.7 & 21.7 & 109 & 36 & 12 & 15 & 39 \\
\hline October & 15.6 & 15.0 & 17.2 & 15.0 & 15.0 & 14 & 27 & 19 & 74 & 34 \\
\hline November & 11.1 & 10.0 & 9.4 & 10.0 & 8.3 & 0 & 4 & 6 & 2 & 17 \\
\hline December & 4.4 & 3.3 & 3.9 & 4.4 & 3.9 & 0 & 38 & 29 & 6 & 16 \\
\hline Annual & 15.7 & 15.2 & 14.8 & 14.4 & 15.0 & 526 & 415 & 329 & 473 & 399 \\
\hline
\end{tabular}




\section{Statistical Analysis}

Post-Rotation soil test results and total annual DM yield for the first production year of alfalfa were subjected to the mixed procedure of SAS [12] to compare the main effects of Test, Rotation, and the Test $\mathrm{x}$ Rotation interaction. A replicate was identified as unique within a Test and considered random. All differences reported are significant at $p \leq 0.05$. When an interaction was significant, protected least significant differences were used to determine where differences occurred using the PDMIX800 macro [13].

\section{Results and Discussion}

\subsection{Weather Conditions}

Temperatures in Years 1 and 2, during the rotation phase and for alfalfa establishment, were conducive to the growth of each crop during their respective growing season (Table 3) $[11,14,15]$. Irrigations were applied to supplement less than adequate precipitation and promote crop establishment and production during those years. During Year 3, the first production year for the replanted alfalfa, March was much warmer than average for Test 1 and cooler than average for Test 2, while April of Year 3 for Test 1 was cooler than average (Table 3). These factors, coupled with the inability to irrigate until canal water is available in mid-April, consistently reduce first cutting yields of alfalfa at this location. Otherwise, temperatures for the remainder of the Year 3 growing seasons were conducive for alfalfa production (Table 3) and irrigations were applied to supplement precipitation and promote alfalfa growth.

\subsection{Pre-Alfalfa Replanting Soil Test Results}

Results of statistical analyses for soil testing immediately after seedbed preparation and alfalfa replanting are presented in Table 4. No differences existed among main effect Rotation treatments, but differences in the main effect of Tests were observed for all variables, except $\mathrm{pH}, \mathrm{P}, \mathrm{Zn}, \mathrm{Mn}, \mathrm{Ca}, \mathrm{Mg}$, and CEC. Hickman [16] found no difference in $\mathrm{P}, \mathrm{K}, \mathrm{Ca}, \mathrm{Mg}, \mathrm{Mn}, \mathrm{Zn}, \mathrm{Cu}$, or Na after 16 years of either moldboard plowing or no-tillage practices in various maize-soybean (Glycine max L.)-wheat rotations in a clay loam soil.

The difference between Tests is likely associated with soil type (Tables 1 and 4). Soil $\mathrm{N}, \mathrm{S}, \mathrm{Fe}$, and $\mathrm{Cu}$ differences between Tests could be attributed to OM content after the renovation phase and dynamic soil physical and chemical processes unique to soil type [17]. Alijani et al. [18] found that moldboard plowing incorporates residues more deeply into the soil, resulting in more rapid decomposition, thereby reducing soil organic carbon and $\mathrm{N}$ levels as indicated by the ranking of soil $\mathrm{N}$ among Rotation treatments in the present study (Table 4: one tillage period for ALF, two for SS1, and three each for SS2 and WW/SS) [19]. On the other hand, Dixit et al. [20] reported that after 4 years of various combinations of tillage treatments in a sorghum + cowpea (Vigna unguiculata L.)-wheat cropping system, there was no difference in soil $\mathrm{pH}, \mathrm{N}, \mathrm{P}$, or $\mathrm{K}$. 


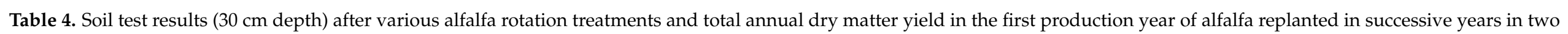
separate tests and at Tucumcari, NM, USA. Values are the lsmeans of two replicates in Test 1 or four replicates in Test 2.

\begin{tabular}{|c|c|c|c|c|c|c|c|c|c|c|c|c|c|c|c|c|c|}
\hline & \multicolumn{15}{|c|}{ Soil Test Results } & \multirow{2}{*}{\multicolumn{2}{|c|}{ Alfalfa Yield }} \\
\hline & $\mathrm{pH}$ & EC & OM & $\mathbf{N}$ & $\mathbf{P}$ & K & $\mathrm{S}$ & $\mathrm{Zn}$ & $\mathrm{Fe}$ & Mn & $\mathrm{Cu}$ & $\mathrm{Ca}$ & $\mathrm{Mg}$ & $\mathrm{Na}$ & CEC & & \\
\hline Test & & 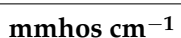 & $\%$ & \multicolumn{12}{|c|}{ ppm } & \multicolumn{2}{|c|}{$\mathrm{Mg} \mathrm{ha}^{-1}$} \\
\hline 1 & 8.29 & 0.27 & 0.49 & 3.1 & 12.4 & 183 & 9.9 & 0.34 & 5.48 & 4.31 & 0.28 & 2738 & 329 & 43.1 & 17.1 & 5.91 & \\
\hline 2 & 8.38 & 0.44 & 1.08 & 29.7 & 10.0 & 236 & 38.7 & 0.29 & 8.76 & 4.77 & 0.49 & 2702 & 345 & 80.3 & 17.4 & 5.19 & \\
\hline \multicolumn{18}{|l|}{ Rotation } \\
\hline ALF & 8.25 & 0.39 & 0.86 & 22.8 & 11.5 & 205 & 22.8 & 0.32 & 7.46 & 4.74 & 0.38 & 2708 & 350 & 64.4 & 17.3 & 6.43 & $\mathrm{AB}$ \\
\hline SS1 & 8.40 & 0.36 & 0.71 & 17.2 & 12.4 & 234 & 24.6 & 0.30 & 6.73 & 4.71 & 0.38 & 2779 & 339 & 54.5 & 17.5 & 5.30 & B \\
\hline SS2 & 8.38 & 0.34 & 0.75 & 13.3 & 9.3 & 190 & 27.0 & 0.32 & 7.41 & 4.50 & 0.39 & 2786 & 326 & 66.1 & 17.5 & 6.92 & A \\
\hline WW/SS & 8.30 & 0.34 & 0.80 & 12.4 & 11.5 & 209 & 22.8 & 0.32 & 6.86 & 4.21 & 0.38 & 2609 & 333 & 61.9 & 16.6 & 3.54 & C \\
\hline Test (T) & 0.49 & 0.02 & 0.01 & 0.01 & 0.45 & 0.04 & 0.01 & 0.51 & 0.04 & 0.52 & 0.01 & 0.96 & 0.49 & 0.01 & 0.94 & \multicolumn{2}{|c|}{0.14} \\
\hline Rotation (R) & 0.40 & 0.92 & 0.46 & 0.57 & 0.80 & 0.64 & 0.96 & 0.99 & 0.89 & 0.86 & 1.00 & 0.46 & 0.74 & 0.49 & 0.67 & \multicolumn{2}{|c|}{0.01} \\
\hline $\mathrm{T} \times \mathrm{R}$ & 0.03 & 0.86 & 0.98 & 0.45 & 0.84 & 0.83 & 0.73 & 0.90 & 0.89 & 0.94 & 0.43 & 0.27 & 0.46 & 0.81 & 0.53 & \multicolumn{2}{|c|}{0.01} \\
\hline
\end{tabular}

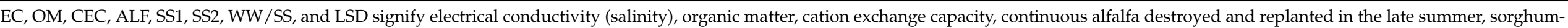

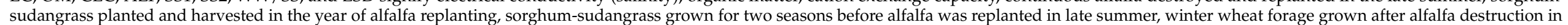

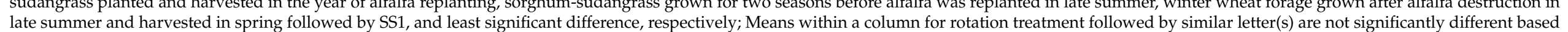
on a $5 \% \mathrm{LSD}$. 
Despite the lack of any main effect differences for soil $\mathrm{pH}$, the Test $\mathrm{x}$ Rotation interaction was significant (Tables 4 and 5).

Table 5. The test $\mathrm{x}$ rotation treatment interactions for soil $\mathrm{pH}(30 \mathrm{~cm}$ depth) and first production year alfalfa dry matter yield after various rotation treatments at Tucumcari, NM, USA. Values are the lsmeans of two replicates in Test 1 or four replicates in Test 2.

\begin{tabular}{lcc}
\hline Rotation & $\mathbf{1}$ & Test \\
& $\mathrm{pH}, 5 \% \mathrm{LSD}=0.29$ & $\mathbf{2}$ \\
ALF & $8.35 \mathrm{ABC}$ & $8.15 \mathrm{C}$ \\
SS1 & $8.37 \mathrm{ABC}$ & $8.43 \mathrm{AB}$ \\
SS2 & $8.33 \mathrm{ABC}$ & $8.43 \mathrm{AB}$ \\
WW/SS & $8.10 \mathrm{BC}$ & $8.50 \mathrm{~A}$ \\
& Yield, $\mathrm{Mg} \mathrm{ha}-1,5 \% \mathrm{LSD}=2.00$ & $4.91 \mathrm{~B}$ \\
ALF & $7.95 \mathrm{~A}$ & $4.86 \mathrm{~B}$ \\
SS1 & $5.75 \mathrm{~B}$ & $5.54 \mathrm{~B}$ \\
SS2 & $8.30 \mathrm{~A}$ & $5.44 \mathrm{~B}$ \\
WW/SS & $1.64 \mathrm{C}$ & \\
\hline
\end{tabular}

LSD, ALF, SS1, SS2, and WW/SS signify least significant difference, continuous alfalfa destroyed and replanted in the late summer, sorghum-sudangrass planted and harvested in the year of alfalfa replanting, sorghumsudangrass grown for two seasons before alfalfa was replanted in late summer, and winter wheat forage grown after alfalfa destruction in late summer and harvested in spring followed by SS1, respectively; lsmeans within an interaction followed by similar letter(s) are not significantly difference based on the 5\% LSD.

No differences existed between Tests for any Rotation treatment other than WW/SS, which had greater $\mathrm{pH}$ in Test 2 than in Test 1 and was significantly different from ALF in Test 2, while SS1 and SS2 were intermediate. Bhatt et al. [21] stated that soil pH is influenced by factors such as topography, parent material, climate, texture, and time and that soils high in $\mathrm{OM}$ and clay are more resistant to $\mathrm{pH}$ changes. The soils in the present study were both sandy and low in OM. Alijani et al. [18] reported a very rapid pH change due to tillage and fertilization compared to other reports they cited. Thompson and Whitney [22] reported that soil $\mathrm{pH}$ in the surface $7.5 \mathrm{~cm}$ was greater during the wheat phase of a sorghum-wheat-fallow rotation than for the sorghum phase, which followed a fallow period after the wheat phase. Perhaps the soil $\mathrm{pH}$ after the alfalfa-WW-SS Rotation in WW/SS in Test 1 was less influenced by the soil type with less OM than the soil in Test 2 (Table 4). Kettler et al. [9] reported a pH increase in the surface $7.5 \mathrm{~cm}$ after moldboard plowing a long-term no-till wheat-fallow cropping system compared to undisturbed soil. This could be a similar effect as the increase observed in Test 2 of the present study for SS1, SS2, and WW/SS compared to ALF (Table 4), which might also be a subtle soil type (Test) difference associated with greater OM (Table 3). They [9] and Thompson and Whitney [22] attributed the increase in soil $\mathrm{pH}$ to soil inversion that brought higher $\mathrm{pH}$ soil from deeper in the profile to the surface.

Wozniak [23] stated that tillage systems and quality of post-harvest residues influence soil chemical properties. Butterly et al. [24] stated that agricultural residues can actually have a liming effect when added to the soil. Therefore, the difference in $\mathrm{pH}$ in Test 2 may also be related to the Rotation species (SS or WW) (Table 5) and the amount of previous crop residue that was incorporated before alfalfa was replanted, compared to ALF, although no evaluation of crop residue was made. Butterly et al. [24] reported that while a short-lived reduction in $\mathrm{pH}$ occurred, possibly due to nitrification, over the next $59 \mathrm{~d}, \mathrm{pH}$ increased, except for wheat residue, which increased $\mathrm{pH}$ immediately and then, depending on initial soil $\mathrm{pH}$, either remained unchanged (initial soil $\mathrm{pH}$ 6.2) or decreased (initial soil $\mathrm{pH} 4.5$ ). Wozniak [23] reported greater soil pH after wheat culture than after pea (Pisum sativa L.) culture. Butterly et al. [24] concluded that rapid ( $<14 \mathrm{~d}$ after incorporation) $\mathrm{pH}$ changes were due to alkalinity that would persist whether it was released from either the soluble or insoluble fraction of plant residue. In the present study, the incorporation of the root and 
stubble residue from one (SS1) or two (WW/SS and SS2) cereal crops may have contributed to the difference in $\mathrm{pH}$ between those treatments and ALF in Test 2 (Table 4).

Conventional tillage with residue incorporation also influences soil organic carbon storage [18] and other properties [20], but it also can have detrimental effects [8,20]. Kettler et al. [9] stated that, while plowing after long-term no-tillage could provide temporary beneficial effects, continuous annual plowing over a 22-year period resulted in reduced soil health and increases in erosion. Two tillage events during a short 2-year rotation to replant alfalfa, such as those implemented in the present study, should not have such long-term effects.

\subsection{First Production Year Alfalfa Dry Matter Yield}

The results of statistical analysis for total annual DM yield data are presented in Table 4, which shows significant effects for Rotation and the Test $x$ Rotation interaction. Annual alfalfa DM yields in these Tests were slightly less than those measured in other studies at this location for alfalfa planted in mid-September [25]. Differences are likely due to alfalfa variety, irrigation technique and amount, soil test, and other environmental influences. Test 2 yields were less than Test 1 yields (Table 4 ) due to the number of harvests taken from each test (six harvests for Test 1, but only four harvests for Test 2).

Means for the Test $x$ Rotation interaction are shown in Table 5. Despite the difference in yield between Tests for ALF and SS2, yield rankings for all Rotations, except WW/SS, were similar between Tests, which likely contributed to the significant main effect for Rotation shown in Table 4. Reduced yields of alfalfa across Tests following SS1 (Table 4) may indicate that alfalfa stand destruction in spring followed by rotation to a short-season summer annual crop before replanting in late summer may not be sufficient to prevent yield reductions associated with autoconditioning due to poor seedling growth caused by autotoxicity [5,7]. Yields of ALF were never significantly less than those of SS2, which had the longest rotation interval (Table 5). Xuan et al. [26] reported that some alfalfa phytotoxins were effective for control of other species for the first $10 \mathrm{~d}$ after incorporation, but effects were minimal by 20-25 d. Jennings and Nelson [5] reported less yields when alfalfa was no-till planted in spring after termination 0.5 or 6 months previously compared to an 18-month interval, with a 12-month interval being intermediate in a silt loam soil. There was no difference between a 0.75 -month interval before replanting and an 18-month interval, with no explanation about why this happened [5]. No rotation crops were grown in that study [5] and no tillage was done between stand destruction and alfalfa replanting.

Seguin et al. [7] reported that a 2-week delay in planting after plowing led to reduced yields compared to planting immediately. Lauriault et al. [25] reported long-term reduced yield associated with a delayed planting date on 3-week intervals from spring into autumn on land not previously in alfalfa at one location, as did Seguin et al. [7], due to initial stand density for mid-summer plantings at another location. They [7] also reported that yields in the year after the seeding of alfalfa immediately following alfalfa were less than yields of alfalfa following a control crop, suggesting that the effects of autotoxicity may be delayed and become expressed later through autoconditioning [5,7]. At any rate, because of inconsistencies in evidence of autotoxicity, the authors [7] concluded that any delay in replanting may not be justified.

The Test $x$ Rotation interaction for DM yield (Tables 4 and 5) was due to the difference between Tests for yield of WW/SS in relation to the other Rotation treatments. Kalinova [1] and Ferreira and Reinhardt [27] cited others reporting allelopathic effects against weeds by major grain crops, including sorghum and wheat. Xuan [26] cited others reporting that soil activity of allelochemicals is influenced by multiple soil factors and that the soil concentration of a major allelochemical produced by sorghum was drastically reduced within a week after incorporation. Perhaps the wheat in the present study exhibited some allelopathy against the alfalfa and these varied results for WW/SS indicate the possibility that using wheat in the rotation is detrimental. A difference in alfalfa stand density was observed among the Rotation treatments in Test 1, such that WW/SS alfalfa stands were 
considerably more open than the other Rotation treatments (data not presented). This did not occur in Test 2. Contrary to the results of the present study, Ferriera and Reinhardt [27] reported the greatest alfalfa yields following wheat, with only alfalfa following annual ryegrass (Lolium multiflorum Lam.) having significantly lower yields and several other rotation species causing an intermediate response. As with other crop species [1], the cultivar of wheat may make the difference, but in the present study, the same cultivar was used in both Tests.

While alfalfa autotoxins leach from leaves, leading to buildup in the soil despite regular removal for the forage $[7,26]$, for each Rotation treatment in the present study, the alfalfa was harvested immediately prior to plowing to remove top growth and limit incorporation of leaves into the soil because leaves have the greatest levels of autotoxic compounds [3]. Kalinova [1] reported that different genotypes of buckwheat (Fagopyrum esculentum Moench) had greater phytotoxic compounds in different plant parts and Xuan [26] and Ferriera and Reinhardt [27] reported differences among alfalfa genotypes in levels of autotoxins.

Many studies have demonstrated that alfalfa can be successfully re-planted in spring after a minimum of two weeks after destroying the original stand with moldboard plowing while others concluded that rotating to another crop for at least one year was necessary $[2,5,7]$. In addition to alfalfa genotype [7] and growth environment [5] being factors both in levels of autotoxins produced [27] and the response to those autotoxins, soil type influences how long the allelopathic substances persist in the soil, with sandy soils having a shorter period of persistence due to leaching, although they also can induce greater effects of autotoxicity [7]. Because alfalfa's allelopathic effects on other plant species, including legumes and weeds [27], is less on sandy soils than on clay soils [6], it is possible that in the irrigated semiarid, subtropical southwestern USA, and similar environments, where deep, well-drained, sandy soils with low organic matter [6] are prominent and heavy applications of irrigation water are applied, the rotation period need not be as long. Additionally, moldboard plowing to destroy the alfalfa, even for ALF, which was replanted about 1 month after the original alfalfa was destroyed, and other cultivation practices to prepare the final seedbed would have thoroughly mixed the upper $30 \mathrm{~cm}$ of the soil, thereby diluting any residual allelopathic metabolites, in addition to frequent heavy irrigation applications for alfalfa germination and establishment, which may have leached the autotoxins below the germination zone more so in the Quay fine sandy loam (Test 1) than in the Canez fine sandy loam (Test 1), based on each soil's water holding capacity (Table 1).

\section{Conclusions}

Soil type and renovation/rotation strategy may influence soil fertility prior to replanting alfalfa, but soil fertility did not appear to influence alfalfa re-establishment or first production year yields. Soil type may have influenced the concentrations of autotoxins in sandy soils based on water holding capacity under heavy irrigation. Consistent with the reports of others, alfalfa stand destruction and replanting with no intervening crop rotation may be feasible in sandy soils with irrigation in the semiarid, subtropical southwestern USA and similar environments. However, rotating to another crop for two years would provide some insurance against potential autotoxicity, as opposed to rotating for a single year. Including wheat in the alfalfa renovation/rotation process may be detrimental; however, the results were not consistent, even when using the same wheat variety. Results of the present study provide useful information about some crop rotation strategies for potentially avoiding autotoxicity when replanting alfalfa in semiarid, subtropical regions. Additional research is needed to explore other crops and rotation strategies in such environments to give producers more options.

Author Contributions: Conceptualization, L.M.L.; methodology, L.M.L. and M.K.D.; software, L.M.L.; validation, L.M.L. and M.K.D.; formal analysis, L.M.L. and M.K.D.; investigation, L.M.L.; resources, L.M.L.; data curation, L.M.L.; writing—original draft preparation, L.M.L.; writing—review and editing, L.M.L. and M.K.D.; visualization, L.M.L.; supervision, L.M.L.; project administration, 
L.M.L.; funding acquisition, L.M.L. and M.K.D. All authors have read and agreed to the published version of the manuscript.

Funding: Salaries and research support were provided by state and federal funds appropriated to the New Mexico Agricultural Experiment Station. This research was also partially supported by Hatch Projects 1-5-27458, NM-LAURIAULT-10H (accession 0221381), NM-LAURIAULT-14H (accession 1004803), NM-LAURIAULT-19H (Accession 1021538), and NMDARAPUNENI-16H (accession 1011673).

Data Availability Statement: Data are available upon reasonable request from the authors.

Acknowledgments: The authors gratefully acknowledge technical and field assistance by Calvin Henson, Martin Mead, and Larry Perkins and secretarial assistance by Patty Cooksey, all at Tucumcari; the staff with the NMSU Library Document Delivery Service; the NMSU College of Agricultural, Consumer and Environmental Sciences Information Technology; and other University support services.

Conflicts of Interest: The authors declare no conflict of interest and the funders had no role in the design of the study; in the collection, analyses, or interpretation of data; in the writing of the manuscript, or in the decision to publish the results.

\section{References}

1. Kalinová, J. Varietal Differences in Allelopathic Potential of Common Buckwheat (Fagopyrum esculentum Moench). Cereal Res. Commun. 2008, 36, 397-408. [CrossRef]

2. Jennings, J.A.; Nelson, C.J. Zone of Autotoxic Influence around Established Alfalfa Plants. Agron. J. 2002, 94, 1104-1111. [CrossRef]

3. Chon, S.; Nelson, C.J.; Coutts, J.H. Osmotic and Autotoxic Effects of Leaf Extracts on Germination and Seedling Growth of Alfalfa. Agron. J. 2004, 96, 1673-1679. [CrossRef]

4. Chung, I.-M.; Seigler, D.; Miller, D.A.; Kyung, S.-H. Autotoxic Compounds from Fresh Alfalfa Leaf Extracts: Identification and biological activity. J. Chem. Ecol. 2000, 26, 315-327. [CrossRef]

5. Jennings, J.A.; Nelson, C.J. Rotation Interval and Pesticide Effects on Establishment of Alfalfa after Alfalfa. Agron. J. 2002, 94, 786-791. [CrossRef]

6. $\quad$ El-Darier, A.M.; Abdelaziz, H.A.; El-Dien, M.H.Z. Effect of Soil Type on the Allelotoxic Activity of Medicago sativa L. Residues in Vicia faba L. Agroecosystems. J. Taibah Univ. Sci. 2014, 8, 84-89. [CrossRef]

7. Seguin, P.; Sheaffer, C.C.; Schmitt, M.A.; Russelle, M.P.; Randall, G.W.; Peterson, P.R.; Hoverstad, T.R.; Qiring, S.R.; Swanson, D.R. Alfalfa Autotoxicity: Effects of Reseeding Delay, Original Stand Age, and Cultivar. Agron. J. 2002, 94, 775-781. [CrossRef]

8. Darapuneni, M.K.; Lauriault, L.M.; Angadi, S.V. Alfalfa Termination Strategies Determine Subsequent Wheat and Haygrazer Forage Yield and Nutritive Value. Crop. Forage Turfgrass Manag. 2019, 5, 190034. [CrossRef]

9. Kettler, T.A.; Lyon, D.J.; Doran, J.W.; Powers, W.L.; Stroup, W.W. Soil Quality Assessment after Weed-Control Tillage in a No-Till Wheat-Fallow Cropping System. Soil Sci. Soc. Am. J. 2000, 64, 339-346. [CrossRef]

10. Olsen, S.R.; Cole, C.V.; Watanabe, F.S.; Dean, L.A. USDA Circular 939, Estimation of Available Phosphorus in Soils by Extraction with Sodium Bicarbonate; U.S. Government Printing Office: Washington, DC, USA, 1954; 19p.

11. Lauriault, L.M.; Marsalis, M.A.; VanLeeuwen, D.M. Planting Date Affects Rainfed Sorghum Forage Yields in Semiarid, Subtropical Environments. Forage Grazinglands 2012, 10, 1-7. [CrossRef]

12. SAS Institute. The SAS 9.3 for Windows; SAS Institute Inc.: Cary, NC, USA, 2013.

13. Saxton, A.M. A macro for converting mean separation output to letter groupings in Proc Mixed. In Proceedings of the 23rd SAS Users Group International, Nashville, TN, USA, 22-25 March 1998; Jansen, L., Ed.; SAS Institute: Cary, NC, USA, 1998; pp. 1243-1246.

14. Fribourg, H.A.; Strand, R.H. Influence of Seeding Dates and Methods on Establishment of Small-seeded Legumes 1. Agron. J. 1973, 65, 804-807. [CrossRef]

15. Coblentz, W.K.; Walgenbach, R.P. Fall Growth, Nutritive Value, and Estimation of Total Digestible Nutrients for Cereal-Grain Forages in the North-Central United States 1. J. Anim. Sci. 2010, 88, 383-399. [CrossRef] [PubMed]

16. Hickman, M.V. Long-Term Tillage and Crop Rotation Effects on Soil Chemical and Mineral Properties. J. Plant Nutr. 2002, 25, 1457-1470. [CrossRef]

17. Hamarashid, N.; Othman, M.; Hussain, M. Effects of Soil Texture on Chemical Compositions, Microbial Populations and Carbon Mineralization in Soil. Egypt J. Exp. Biol. 2010, 6, 59-64.

18. Alijani, K.; Bahrani, M.J.; Kazemeini, S.A. Short-Term Responses of Soil and Wheat Yield to Tillage, Corn Residue Management and Nitrogen Fertilization. Soil Tillage Res. 2012, 124, 78-82. [CrossRef]

19. Awale, R.; Machado, S.; Rhinhart, K. Soil Carbon, Nitrogen, pH, and Crop Yields in Winter Wheat-Spring Pea Systems. Agron. J. 2018, 110, 1523-1531. [CrossRef]

20. Dixit, A.K.; Agrowal, R.K.; Das, S.K.; Sahay, C.S.; Choudhary, M.; Rain, A.K.; Kumra, S.; Kantwa, S.R.; Palsaniya, D.R. Soil Properties, Crop Productivity and Energetics under Different Tillage Practices in Fodder Sorghum + Cowpea-Wheat Cropping System. Arch. Agron. Soil Sci. 2019, 65, 492-506. [CrossRef] 
21. Bhatt, T.D.; Bector, V.; Singh, M.; Singh, D. Performance Evaluation of Real-Time Soil pH Measuring System in Different Tillage Systems. Agric. Engr. Today 2017, 41, 26-31.

22. Thompson, C.A.; Whitney, D.A. Effects of 30 Years of Cropping and Tillage Systems on Surface Soil Test Changes. Commun. Soil Sci. Plant Anal. 2000, 31, 241-257. [CrossRef]

23. Woźniak, A. Chemical Properties and Enzyme Activity of Soil as Affected by Tillage System and Previous Crop. Agriculture 2019, 9, 262. [CrossRef]

24. Butterly, C.R.; Kaudal, B.B.; Baldock, J.A.; Tang, C. Contribution of soluble and insoluble fractions of agricultural residues to short-term pH changes. Eur. J. Soil Sci. 2011, 62, 718-727. [CrossRef]

25. Lauriault, L.M.; Marsalis, M.A.; Groesbeck, J.D. Revisiting alfalfa planting dates for the semiarid U.S. Southwest. Agron. J. 2020, 112, 2006-2019. [CrossRef]

26. Xuan, T.D.; Tawata, S.; Khanh, T.D.; Chung, I.M. Decomposition of Allelopathic Plants in Soil. J. Agron. Crop. Sci. 2005, 191, 162-171. [CrossRef]

27. Ferriera, M.I.; Reinhardt, C.F. Field Assessment of Crop Residues for Allelopathic Effects on Both Crops and Weeds. Agron. J. 2010, 102, 1593-1600. [CrossRef] 